\title{
Sufism in Malaysia and its impact on the revival of the Islamic Dawah
}

\author{
Amr Mohamed Sayed Imam \\ Assistant Professor of Dawah and Religions, \\ Sultan Abdul Halim Mu'adzam Shah International Islamic University, Malaysia \\ doctor.amr80@yahoo.com \\ Mohamed Ebrahim El-Sherbiny Sakr \\ Assistant Professor of Dawah and Religions, \\ Sultan Ahmad Shah Pahang Islamic University- Malaysia (Unipsas) \\ meesakr67@gmail.com
}

\begin{abstract}
There is no doubt that the science of Sufism became an essential part of our Islamic heritage, although it was not popularized as a term and concept until the third century AH.The science of Sufism focused on the spiritual aspect of the heart. The purification of the soul and the soul is the basis of the science of Sufism. Therefore, this aspect had a great impact on Islamic societies, especially Malaysian society. Who was affected by some mystical manifestations, such as wirds and remembrances, and other Islamic rituals, and passed on from generation to generation, and the persistence of it had an effect on the survival of Islam on the souls of the youth and the young, men and women, and it also had an evident effect on nonMuslims, who are many. They are destined to live among Muslims.Therefore, the primary objective of this study was: An observation of some Sufi manifestations that had a good effect in Malaysian society, and the preservation of these aspects that are the piety of hearts, as well as the rooting of these manifestations from the legal point of view and responding to the suspicions that were raised about them.
\end{abstract}

Keywords: Sufism- Dawah- Islamic- Malaysia 


\section{Sufism in Malaysia and its impact on the revival of the Islamic Dawah}

\section{Introduction}

This is a good research through which we wanted to find out some Sufism ceremonies that affected the Muslims of Malaysia and transmitted them from their fathers and grandfathers. which is in its entirety from the authenticity of Islam, and continuing to do it had an effect on the survival of Islam in the hearts of the youth and the young, men and women, and it also had a clear effect on many of non-Muslims, live among Muslims, so the concern for these ceremonies was like a call these people to Islam. In addition, we wanted from this research to monitor some of these ceremonies in order to be a motivation for Muslims to preserve these rituals, it is certainly out of the piety of the heart. in this research the response will come to Whoever describes these ceremonies as a bid'ah, within the framework of sound scientific research.

\section{RESEARCH PROBLEM}

The problem of the research is in the fact that there are many concepts and principles have sneak into the minds and hearts of some young people in Malaysia, which made them describe some of the acts of worship issued by their Muslim brothers as a bid'ah. So, this research was to return the dhikr that were recited after the prayers and other litany, that Muslims are keen on, to their legal origins and to explain the scholars' opinion about them. Then, the research clarifies the scholars 'opinion about dhikr that were recited after the prayers and other litany. Hence, the research clarifies the necessity to observe these worships revives Islam in the hearts.in addition, the research clarifies that adopting a wrong method of inference and describing a society as a heresiarch leads to the emergence of extremist thought.

\section{Research questions:}

- What are the Adhkar that Muslims in Malaysia keen on?

- What is the effect of adhering to these litany and dhikr on the Muslim community in Malaysia? 
Amr Mohamed Sayed Imam\& Mohamed Ebrahim El-Sherbiny Sakr 126

- Do these Adhkar have an effect on Islamic Dawah in Malaysia?

- How can we respond to those who describe these practices as a bid'ah?

\section{Previous studies:}

1- Sufi Orders in Malaysia and their Impact on the Islamic Call and the Islamic Community - Soliman bin Ibrahim bin Omar - Al-Azhar University - Faculty of Fundamentals of Religion and Da`wah - (Cairo) 1999

2- Sufi Literature in the Malay Archipelago - Rossni bin Sama - Annals of Heritage, Mostaganem University, 10th issue 2010

\section{Research Objectives:}

1. Learning about the most important dhikr that Muslims in Malaysia restrict.

2. Explaining the effect of being binding about these litanies on the Malaysian society in general.

3. Responding to those who describe these practices as a bid'ah, by returning the dhikr to its origins.

\section{Research Methodology:}

The inductive and analytical approach, so I followed what was written about the Malaysian society being affected by the mystical spiritual manifestations and analyzed these aspects by explaining the Islamic ruling on them. With the statement of its impact on the revival of the Islamic dawah in Malaysia.

This study came in Introduction, Preface, Four Topics, and a conclusion. As for the Introduction, we explained the importance of the topic, the reasons for choosing it, the research problems, and its objectives. As for the Preface, we mentioned Topics of the research: As for the First Topic, it came under the title: Adhkar after prayer, and the second topic: under the title: Dhikr in congregation, the Third Topic under the title: Tahlil and Yaseen's Reciting, and as for the Fourth Topic: Dawah Effects of Sufi ceremonies in Malaysia, the conclusion contains the most important findings and recommendations that came out of the research. 


\section{Sufism in Malaysia and its impact on the revival of the Islamic Dawah}

Then the most important Sources, References, and Index of Contents.

Finally, we ask Allah to make this work sincere for His honorable sake, and to accept it, praise be to Allah in the beginning and the conclusion.

\section{Preface:}

Defining concepts is one of the priority tasks in scientific research. This research included several terms; It should be defined. This will be clear as follows:

\section{Definition of Sufism:}

Sufism is an Islamic madhhab, but according to the Sufi vision it is not a madhhab, but rather one of the three pillars of the religion (Islam, Faith, Ihsan). As jurisprudence concerned with the teachings of the Sharia of Islam and the science of belief concerned with faith, Sufism is concerned with achieving the Ihsan, education and behavior, education of soul and heart, purifying them from depravity, and acquiring virtues; Which is the third pillar of the complete Islamic religion after the two pillars of Islam and Iman, and it was compiled by the hadith of Gabriel, and Ibn Ashir mentioned it in his Matn (Al-Murshid al-Mu'een, and he urged more to achieve Ihsan, because of its great destiny and affair. (Al-Khalidi, 2018 AD, p.: 50)

The Ihsan, as narrated in the hadith of Gabriel, (the prophet (PBUH) said, "It is to worship Allah as if you are seeing Him; and although you do not see Him, He sees you) (Sahih Al-Bukhari No. 50 and Sahih Muslim No. 9), and it is a method or path that a servant takes to reach Allah; that is, to knows about Him. And that is through diligence in acts of worship and avoiding prohibitions, raising the soul and purifying the heart from bad manners, and sweetening it with good morals, through the abundance of wird and rituals with committing to perform the obligations.

This approach derives its origins and branches from the Qur'an and the Prophet's Sunnah and the scholars Jurisprudence unless a special text is 
not stipulated in the Quran and Sunnah. It is a science like the science of jurisprudence. It is a science like the science of jurisprudence, it has its doctrines, schools, jurisprudences, and imams who built its pillars and rules, like other sciences, generation after generation until they made it the knowledge of his superiority in the science of Sufism, the science of Tazkiah, the science of ethics, the science of behavior, or the science striving to Allah. The scholars wrote the books to clarify its origins, branches and rules, and among the most famous of these books are: al-Hikam al'Atta'iyyah by Ibn Ata Allah al-Iskandari, The Rules of Sufism (Qawaid al-tasawwuf by Sheikh Ahmad Zarruq, The Revival of the Religious Sciences by Imam Al-Ghazali, The Al-Risala al-Qushayriyya by Imam AlQushayri, and the identification of the doctrine of the people of Sufism by Imam Abu Bakr Al-Kalabadi and others.

\section{About Malaysia}

Malaysia is in southeast Asia and is crescent in shape, close to the equator, and occupies two prominent regions, first: the Peninsula of Malaysia and includes most of the states of Malaysia bordered to the north by Thailand and to the south by Singapore. The second region includes the states of Sabah and Sarawak and is located on the western coast of Borneo Island and separates the two regions the South China Sea is about $750 \mathrm{~km}$. through Malacca Strait, Malaysia is connected to the Indonesian island of Sumatra, the Philippines is in the northeastern state of Sabah (Foreign Media Department, Malaysian Foreign Ministry 1994, p. 1: 2)

The land area of Malaysia is 330,434 square kilometers, and this area is separated into two regions by 750 kilometers, the first region of the Malay Peninsula has an area of 587,131 square kilometers, it includes eleven states, and the northern island of Borneo, where there are two states of Sabah and Sarawak, together have an area of 198,874 square kilometers. (Shaker, 1997 AD, Part 2, p. 336.)

The population of Malaysia is 30,485.20 in statistics of the 2015 issued by the Malaysian Ministry of Communications and Multimedia website. 


\section{Sufism in Malaysia and its impact on the revival of the Islamic Dawah}

By the Sufi tendency in our study, we mean: the Muslim community in Malaysia preserving some of the wirds and Adhkar mentioned by some of the great Sufis, and the recitation of the Holy Qur' an with special behavior and specific way, as well as the sounds, words and regular movements in terms of the outputs of the letters and their houses and phonemic arrangement when pronouncing the Qur'an or the dhikr, and its effect in reviving the Dawah to Islam and keeping it alive in the hearts of Muslims, and how keenness on these dhikr sessions has become a slogan for the Dawah in a society where there is also a large number of non-Muslims.

\section{Definition of Dawah:}

The author of Al-Lisan Al-Arab says: "Dawah is given and intended the call and the request. It is said that so-and-so called for us, and I called the man if shouted in his name and summoned him. The Almighty said: "And one of His signs is that the heavens and the earth persist by His command. Then when He calls you out of the earth just once, you will instantly come forth" (Ar-rum: 25). Sometimes it is called and meant to call for something in the sense of urging its intention, and it also comes in the meaning of calling for a cause that is to be proven, or defending it, whether it is true or false, for the first one Allah Almighty said: "Calling upon Him 'alone" is the truth" (Ar-ra'd: 14). And said: "And Allah invites 'all' to the Home of Peace" [Surah Yunus: 25]. And for the second one, falsehood, in the story of Allah said "Joseph prayed, "My Lord! I would rather be in jail than do what they invite me to" [Yusuf: 33]; Yusuf, peace be upon him, prefers to be in jail than Obedience to women and falling into immorality that removes the goodness of this world and the hereafter, and requires Allah's wrath, torment and painful punishment.". (Ibn Manzur, 1414 AH, Part 14/257)

As for defining Da'wah technically: Da'wah can be defined in convention as Islam or the message: From what is mentioned in this concept, Da'wah can be defined as follows:

"The religion that Allah has chosen for the worlds and revealed His teachings as a revelation to the Messenger of Allah, peace be upon him, and 
Amr Mohamed Sayed Imam\& Mohamed Ebrahim El-Sherbiny Sakr 130

preserved it by the Holy Qur'an and the Sunnah of the Prophet." (Barghouth, $2002 \mathrm{AD} / 1423 \mathrm{AH}$, p. 25)

It can also be defined as the process of communicating and missionary of Islam.

Those who viewed Da'wah as a process of communication and missionary defined it by saying:

"The Islamic Da'wah is a complete program that includes in its depths all the knowledge that people need to see the purpose of their lives, and to explore the features of the right road that unite them as righteous." (AlGhazali, 1981 AD, p. 17.).

The Da'wah is communicating Islam to people, teaching it to them, and applying it to the realities of life (Al-Bayanouni, Beirut 1991 A.D., p. 17.) By our discussion we mean the message of Islam, that is: the religion that Allah has chosen for all people.

\section{THE FIRST TOPIC: DHIKR AFTER PRAYER}

There are many dhikrs that the imam is keen on performing it after completing the prayer in Malaysia. So, immediately after the salutation the imam begins to raise his voice with the dhikr, which we will summarize in several Issues, and the worshipers repeat after him in a loud and audible voice until he finishes the dhikr at the end of the prayer, and the first thing that the imam begins with What the Prophet explained in the following hadiths:

\section{First: Forgiveness after Prayer}

Thauban said that when Allah's Messenger finished his prayer, he asked forgiveness three times and said, "O Allah, thou art Peace, and peace comes from Thee. Blessed art Thou, O Possessor of glory and honor." Walid reported: I said to Auza'i: How is the seeking of forgiveness? $\mathrm{He}$ replied: You should say: I beg forgiveness from Allah, I beg forgiveness 


\section{Sufism in Malaysia and its impact on the revival of the Islamic Dawah}

from Allah" (Sahih Muslim number: 591), and in a narration of Aisha in Muslim, 'A'isha said that when Allah's Messenger uttered the salutation, he sat no longer than it took to say, "O Allah, Thou art Peace, and peace

comes from Thee. Blessed art Thou, O Possessor of glory and honor." (Sahih Muslim number: 592) in the narration of Ibn Namir " the words are:" O Possessor of Glory and Honor".

On the authority of A'isha except for the words that he (the Holy Prophet) used to say: " O Possessor of Glory and Honor." (Sahih Mus$\lim$, No. 593)

From these hadiths it becomes clear that: The formula for seeking forgiveness after prayer is: Ask forgiveness of Allah, ask forgiveness of Allah, ask forgiveness of Allah, (Astaghfirullah! Astaghfirullah!), as explained by Imam Al-Ouzai when he was asked about how to seek forgiveness in the hadith. It is a formula bound at the end of prayer that came in the book (Islamic Jurisprudence and its Proofs) by Dr. Wahbah alZuhayli: The fifth chapter, The narrated Adhkar after the prayer:

Dhikr Allah and narrated supplication after the prayer is Sunnah, either immediately after the obligatory prayer if it does not have a later year, such as the Fajr prayer and Asr prayer, or after the completion of the later voluntary prayer, such as the Zuhr, Maghrib and Isha prayers. Because asking for forgiveness compensates for the lack of prayer, and supplication is a way to be rewarded after approaching Allah through prayers.

And he recites the dhikr secretly in the following order except for the imam who wants to teach the attendees, so he is loud until they learn, and the imam turn to the attendees, making his left to the mihrab. Samra said: "Samura b. Jundub said, "When Allah's Messenger had prayed a prayer he turned and faced us.". says: "I seek forgiveness from Allah, three times" or "I seek forgiveness from Allah, the Magnificent, whom there is none worthy of worship but Him, the Living, Al-Qayyum, and I repent to him three times. (Al-Zuhaili, Part 2, p.164) 
Second: None has the right to be worshipped but Allah alone, who has no partner. His is the dominion and his is the praise

the Dhikr narrated at the end of prayer; This Dhikr mentioned in Al-Bukhari hadith...

It was narrated that Warrad said:

"Al-Mughirah bin Shu'bah wrote to Mu'awiyah (Saying) that the Messenger of Allah (- used to say following every prayer, after the taslim: ' $L a$ Ilaha Illallah wahdahu la sharika lah, lahul-mulk wa lahul-hamd wa huwa 'ala kulli shay'in qadir. Allahumma la mani' lima a'taita wa la mu'tia lima mana'ta wa la yanfa'u dhal-jaddi minka al-jadd. (There is none worthy of worship except Allah ( alone with no partner or associate. He is the Dominion and to Him be all praise, and $\mathrm{He}$ can do all things. O Allah, one can withhold what You have given, and none can give what You have withheld, and no wealth or fortune can benefit anyone for from You comes all wealth and fortune.)' (Sahih Al-Bukhari and his pronunciation (5/2332 No. 5971) and Muslim (1/415) 593

So, the hadith is authentic and recorded by Al-Bukhari, so it is permissible to argue by it and recite this Dhikr after prayer.

\section{Third: At-Tasbīh, At-Takbīr, and At-Taḥmīd.}

Many hadiths were received about At-Tasbīh, At-Takbīr, and AtTahmīd after prayer and there are differences in numbers and how, the strongest opinion: Subhaanallaah (33 times), Alhamdu lillāhil (33 times) and Allaahu 'Akbar (33 times) and says to complete a hundred: Lā ilāha illallāh waḥdahu lā sharīka lah, lahu'l-mulku wa lahu'l-ḥamd yuhȳī wa yumīt wa huwa `alā kulli shay'in qadīr.

Narrated Abu Hurairah (RA) Allah's Messenger (政) said: "Whoever glorifies Allah (by saying Subhan-Allah) after every Salat (prayer) thirty-three times, and praises Allah (by saying Alhamdu-lillah) thirtythree times, and exalts Allah (by saying Allahu Akbar) thirty-three times, 


\section{Sufism in Malaysia and its impact on the revival of the Islamic Dawah}

those are ninety-nine in all, and says to complete a hundred: La ilaha illAllahu, wahdahu la sharika lahu, lahul-mulku wa lahulhamdu, wa Huwa 'ala kulli shai'in Qadir (There is nothing which deserves to be worshipped except Allah Alone Who has no partner; to Him belongs the kingdom, to Him praise is due, and He has power over everything), his sins will be forgiven, even if they are as abundant as the foam of the sea."

\section{Fourth: Dhikr after sunset and dawn prayer}

Abu Dharr narrated that: The Messenger of Allah (w) said: "Whoever says at the end of every Fajr prayer, while his feet are still folded, before speaking: 'None has the right to be worshipped but Allah, Alone without partner, to Him belongs all that exists, and to Him is the praise, He gives life and causes death, and He is powerful over all things, (L $\bar{a}$ ilāha illallāh, waḥdahu lā sharīka lahu, lahul-mulku wa lahul-ḥamdu, yuhȳ̄ wa yumītu, wa huwa 'alā kulli shay'in qadīr)' ten times, then ten good deeds shall be written for him, ten evil deeds shall be wiped away from him, ten degrees shall be raised up for him, and he shall be in security all that day from every disliked thing, and he shall be in protection from Shaitan, and no sin will meet him or destroy him that day, except for associating partners with Allah. (Related by At-Tirmidhi and it is his version) (5/515 No 3474) Tirmidhi said this is a hasan gharib sahih hadith.)

(Abd ar-Rahman b. Ghanm reported the Prophet ( as saying, "If anyone says ten times before he departs and turns away his feet after the sunset and the morning prayers, 'There is no Allah but Allah alone who has no partner, to whom belongs the kingdom, to whom praise is due, in whose hand is good, who gives life, causes death, and is omnipotent,' ten blessings will be recorded for him for every time he says it, ten evil deeds will be obliterated, he will be raised ten degrees, it will act as a charm for him from every unpleasantness and from the accursed devil, he will not be taken to account for any sin but polytheism, and he will be among those whose deeds are most excellent, except for one who may excel him by saying something more excellent than he did.") (Ahmed bin Hambal's musnad (4/227), No (18153) and came in Majma al-Zawa'id: reported by 
Amr Mohamed Sayed Imam\& Mohamed Ebrahim El-Sherbiny Sakr 134

Ahmad and its narrators are those who are reported from in the Sahih except Shahr bin Hushab and his hadith is Hasan)

These two hadiths certified as Hasan, and it is permissible to use them as evidence when reciting this adhkar ten times after the morning prayer and the sunset prayer.

\section{Dhikr: "O Allah, protect me from hell":}

Al-Harith b. Muslim at-Tamimi quoted his father as saying that Allah's messenger told him secretly to say seven times when he had finished the sunset prayer, before speaking to anyone, "O Allah, protect me from hell"; for if he said that and died that night, exemption from it would be recorded for him. (Ahmed transmitted it (4/ 234, No 18083), Al-Hafiz in Nata'ag Al-Afkar said this Hadith is Hasan (2/309) Al-Hafiz Ibn Hajar certified this Hadith as Hasan.

\section{Fifth: Reciting Ayat al-Kursi}

Narrated Abu Umamah (RA): Allah's Messenger (絊) said: "Whoever recites Ayat al-Kursi at the end of every obligatory prayer, nothing but death will prevent him from entering Paradise." [An-Nasa'i in Amal al Yaum wa al Lailah (No 100) and Al-Tabarani in Al-Kabir (9/134 with No. 7532 reported it, and Ibn Abd al-Hadi graded it Sahih (authentic)).

\section{Sixth: Reciting Al-Mu'awwidhatayn (The two last Suras of Quran)}

'Uqba b. 'Amir said that "Allah's Messenger ordered him to recite Al-Mu'awwidhat after every prayer." An-Nasa'i reported it in Amal al Yaum wa al Lailah; As in "Tuhfetu'l-eshraf bi-ma'rifeti'l-etraf" (7/ 312), At-Tirmidhi reported it (5/171/2903) Tirmidhi said this is a hadith hasan gharib)

Narrated 'Uqbah bin 'Aamir (RA): said "Allah's Messenger ordered him to recite Al-Mu'awwidhat after every prayer." Abu Dawud reported it in No (1523) and At-Tirmidhi graded it Hasan (good) - No (2903) 


\section{Sufism in Malaysia and its impact on the revival of the Islamic Dawah}

It is noteworthy that the term "Al-Mu'awwidhat" is used for the three surahs: Al-Ikhlas, Al-Falaq and An-Nas, as it was mentioned in the previous narration according to Abu Dawood, may Allah have mercy on him, narrated: "Allah's Messenger ordered him to recite Al-Mu'awwidhat after every prayer." Nawawi said it in "Kitab al-adhkar": chapter: Aladhkar after prayer, and in a narration: "Al-Mu'awwidhat", should read: "Say, 'O Prophet, "He is Allah-One 'and Indivisible", "Say, 'O Prophet, "I seek refuge in the Lord of the daybreak" and "Say, 'O Prophet, "I seek refuge in the Lord of humankind"

In Abu Dawud's narration of "Al-Mu'awwidhat", (Al-Nawawi said: he should read: "Say, 'O Prophet, "He is Allah-One 'and Indivisible", "Say, 'O Prophet, "I seek refuge in the Lord of the daybreak" and "Say, 'O Prophet, "I seek refuge in the Lord of humankind" (Al-Nawawi 1414 Hijri - 1994 AD, part 1, page 73).

\section{Seventh: Reciting Al-Fatiha}

\section{Narrated}

Fatihatil-Kitab; Ayat Al-Kursi; and two verses from Al 'Imran (\{Allah 'Himself' is a Witness that there is no Allah 'worthy of worship' except Him $\}$ and \{Say, 'O Prophet, "O Allah! Lord over all authorities to $\{$ And You provide for whoever You will without limit , are suspending from the Throne, and there is no screen between them and Allah, O Allah, you bring us down to your land, and to whom disobey you, Allah, said: "I swore that none of my slaves would read you after every prayer unless I made Heaven his abode, as it was of him, otherwise, heaven will dwell in it, I looked at him through my eyes every day seventy looks, otherwise I spent for him every day seventy needs, the lowest is forgiveness, I will help him over every enemy and I seek refuge from him." (narrated by Ibn Hibban in "Al-Magrouhen" (1/ 2018) Ibn Al Sunni (No 322) Al-shahamiy Abd Al-khaliq in "Al-Arbaon" (26/2) and the hadith is very weak.

The opinions of the jurists on reciting Surat Al-Fatihah after

\section{the obligatory prayer}


Amr Mohamed Sayed Imam\& Mohamed Ebrahim El-Sherbiny Sakr 136

Some Shaaf'is counted it as a Sunnah following the obligatory prayer. Ibn Hajar al-Haytami says:

(Chapter: In Sunan after prayer and in them:

It is desirable to dhikr "and the adhkaar narrated" after the prayer, including:

I ask Allah for forgiveness three times, O Allah, you are As-salaam and from you is all peace. Blessed are you, O possessor of majesty and Honor, Tasbihah thirty-three times, Tahmid thirty-three times, Takbir thirty-three times and the one hundred: "None has the right to be worshiped except Allah, alone, with no partner. To him belongs all sovereignty and praise, and $\mathrm{He}$ is over all things Omnipotent" and from it: $\mathrm{O}$ Allah, help me to remember You, to give You thanks, and to perform Your worship in the best manner. Recite Surat Al-Ikhlas, Al-Mu'awwidhat, Ayat Al-Kursi and Al-Fatihah.) (Ibn Hajar al-Haytami 1420 Hijri - 2000 AD, part 1, page 109)

Sheikh Al-Bakri Al-Shafii in Iieanat al-Talibin Ealaa Hal 'Alfaz Fath al-Mueyin:

(Abd al-Wahhab al-Sha'rani- May Allah be pleased with him mentioned in his book Al-Dalala Ala Allah Az-wajal, narrated Abi AlAbbas narrated that the Prophet (新) said: I asked twenty-four thousand prophets about using something that the servant would believe in from depriving the faith, and none of them answered me until I met with Muhammad ( so I asked him about that and he said: Until I ask Gabriel, peace be upon him. So, he asked him about that, and he said: Until I ask the Allah of the Glory about it. So, he asked the Allah about that, and Allah Almighty said: Whoever recites the verse of Ayat Al-Kursi and believes the Messenger, until the end of the surah, and Allah bears witness to his saying Islam, "Say, 'O Prophet, "O Allah! Lord over all authorities to his saying "without limit", and Surat Al-Ikhlas, Al-Mu'awwidhat and Al-Fatihah after every prayer, is safe from depriving faith.) (Al-Bakri 1418 Hijri - 1997 $\mathrm{AD}$, part 1, page 215) 


\section{Sufism in Malaysia and its impact on the revival of the Islamic Dawah}

Mentioned in dr. Wahbah al-Zuhayli's book (Islamic Jurisprudence and its Proofs): fifth topic. Al-adhkar after prayer:

(Recites Ayat Al-Kursi, surat Al-Ikhlas: $\{$ Say, 'O Prophet, "He is AllahOne 'and Indivisible; [Al-Ikhlas: 1/112], Al-Mu'awwidhat \{Say, O Prophet, "I seek refuge in the Lord of the daybreak\} [Al-Falaq: 1/113], \{Say, O Prophet, "I seek refuge in the Lord of humankind\} [An-Nas: 1/114] and Al-Fatihah. Narrated Husayn ibn Ali (RA): Allah's Messenger (䔝) said: "Whoever recites Ayat al-Kursi at the end of every obligatory prayer, nothing but death will prevent him from entering Paradise". Narrated Uqba ibn Amir said Allah's Messenger (- ordered him to recite alMu'awwidhat* after every prayer). (Al-Zuhayli, part 2, page 164)

Accordingly, the hadith mentioned in reciting Al-Fatihah after every prayer is very weak, but some of the jurists mentioned it in their books, especially the Shafi' $i$, and perhaps reciting it as a means of supplication has no objection to it.

What is said after Witr prayer: Ubayy b. Ka'b said that Allah's Messenger (- was reciting in Witr prayer with "Glorify the Name of your Lord, the Most High", "Say, 'O Prophet, " 'O you disbelievers!" and "Say, 'O Prophet," "He is Allah-One 'and Indivisible";" if he finished, said: Subhāna 'l-Maliki 'l-Quddūs (Abi Dawood 1423, Ibn Majah 1171 and AlNasa'i [3/ 235 and 244] and Its chain of narrators is authentic). Three times.

\section{Summary of what is said after prayer}

1- (Astaghfirullāha, Astaghfirullāha, Astaghfirullāha) or Astaghfirullaahal-'Adheemal-lathee laa 'ilaaha 'illaa Huwal-HayyulQayyoomu wa 'atoobu 'ilayhi.

2- Allāhumma antas-salām, wa minkas-salām, tabārakta yā dhalJalāli wal-'Ikrām.

3- There is nothing worthy of worship except Allah Alone, who has no partner. To Him belongs the kingdom, to Him praise is due, and He has power over everything. O Allah no one can withhold what You have given, or give what You have withheld and riches cannot avail a wealthy person against You. 
4- Recites Ayat Al-Kursi then surat Al-Ikhlas (once) then surat AlFalaq (once) then surat An-Nas (once), there no objection to reciting Al-Fatihah as a means of supplication.

5- Subhaanallaah (33 times), Alhamdu lillāhil (33 times) and Allaahu 'Akbar (33 times) and says to complete a hundred: Lā ilāha illallāh waḥdahu lā sharīka lah, lahu'l-mulku wa lahu'l-ḥamd yuhȳì wa yumīt wa huwa `alā kulli shay'in qadīr.

6- Then supplicate to Allah.

After the senset and the morning prayers while facing the Qiblah and before speaking:

"Là ilāha illallāh waḥdahu lā sharìka lah, lahu'l-mulku wa lahu'l-ḥamd yuhȳ̄ wa yumìt wa huwa 'alā kulli shay'in qadīr." (10 times) and "O Allah, protect me from hell” (7 times).

After Witr prayer only: Subḥāna 'l-Maliki 'l-Quddūs (3 times) and raise his voice in the third.

A careful observation of Muslims in Malaysia and those who go to their mosques will find that they adhere to many of these adhkar and supplications and are keen on them, and even memorize them by heart, and they also memorize them for their children, which had a clear impact on the spiritual life among Muslims, and this also had a clear effect on showing the rites of Islam. There is no doubt that the rise of minarets with these rites creates a religious spirit in society through which beliefs are manifested, and it is a practical invitation to non-Muslims to learn about Islam and its values, and an invitation as well to Muslims who have occupied by their work and their lives to the witness of these sessions.

Second Topic: Dhikr in Unison and its Impacts on the Spiritual Life in Malaysia

The devotion to maintain Dhikr in the mosques of Malaysia -as detailed in the previous topic- is practiced in unison. There are also assemblies of Dhikr done in houses upon travel for Umrah, before traveling to 


\section{Sufism in Malaysia and its impact on the revival of the Islamic Dawah}

perform Hajj, assemblies of Dhikr done for seeking intercession and reciting $D u^{\prime}$ a $a$ for the sick and the dead, or assemblies of Dhikr practiced at religious occasions. This prompts us to clarify and explain the stance of Mualim Scholars on Dhikr in unison then state the impact of Dhikr in unison assemblies on Da`wah and spiritual life in Malaysia.

\section{First: Dhikr definition linguistically and technically:}

\section{1- Dhikr in linguistics:}

The book "Maqayis Al Lugha" (Scales of the Language) define Dhikr as follows:

The word root is "ذكر" which branch off to include the following stems; "المُنْكِكِ" (Al-Mudhkir) the person that birth a male, "الِِذْكار" (Al-Midhkar) is the one that usually births males, and the other stem is "ذَكَرْتُ الثيء" "

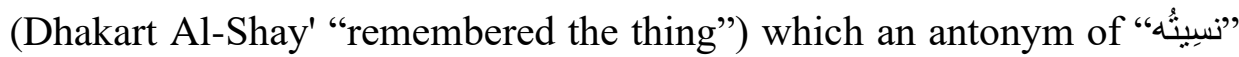
(Nasiatuh "forgot the thing"). "الأنِكُر باللَّلِسان" (to mention it verbally) was

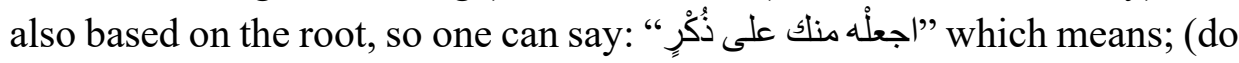
not forget it). (Ibn Faris, Vol. 2, Page: 258)

"الذكر" (Dhikr) could also mean: reputed and praised, Allah the Almighty says: "Șãd. By the Qu'ran, full of reminders (Dhikr)!" (Surat: Saad, Verse 1) which means the honorable. (al-Razi, 1420 A.H.-1999 A.D., Page: 358)

"الذكر" (Dhikr) is used to refer to other meanings including praying and reciting Du aa to Allah; it may also refer to acts of Obedience, praising, Du’aa, Tasbih, reciting Qu'ran, Glorifying, Tasbih, and Tahlil Allah, and praising Allah by all great merits. "الذكر" (Dhikr) may also refer to: the book the include the details of the religion and stating creeds. All the holy books revealed is considered "ذكر" Dhikr, as Allah the Almighty says, "It is certainly We Who have revealed the Reminder (Dhikr), and it is certainly We Who will preserve it." (Surat Al-Hijr, Verse 9), and it is said to be referring only to Qu'ran. (Al-Zabidi- 6/376-377) 
" (Al-Dhikraa) is the abundance of Dhikr which is more eloquent from Dhikr. Allah the Almighty says, “... as a mercy from Us and a lesson (Dhikraa) for people of reason." (Surat: Saad, Verse 43), and "But 'continue to' remind (Dhikr). For certainly reminders (Al-Dhikraa) benefit the believers." (Surat: Adh-Dhariyat, Verse 55). "التنكرة" (Al-Tadhkira) is what is set as a reminder and it is broader than a sign and a token, as Allah the Almighty says; "Now, what is the matter with them that they are turning away from the reminder (Al-Tadhkira)," (Surat Al-Muddaththir, Verse 49). (Al-Ragheb Al-Isfahani - Page 185)

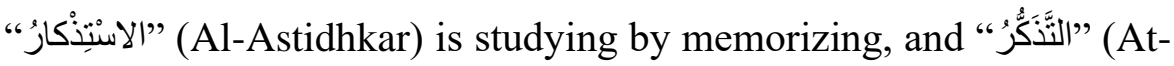
Tdhakkur) is to recall something that has passed. (Ibn Abbad, 1441 A.H.6/235)

\section{2- Dhikr in technicality:}

Imam Ibn al-Qayyim said: Dhikr is to abandon neglect and forgetfulness. (Ibn al-Qayyim, 1419 A.H.- 1999 A.D. Edition, 2/330)

Ibn Ajiba said: if one to mention Dhikr we usually think of the verbal Dhikr which is a strong pillar in the path of connection and is the authentication of the person. Those who are granted Dhikr are given the authentication and those who are deprived of it are to be abandoned. Regular people perform Dhikr by tongue, special people perform it by heart, and the most special of them all perform it by the soul, where secrecy then becomes their witness, they always perform Dhikr and for everything: to know that Allah see them, then the tongue shall be silenced and be as the astonished in public. (Ibn Ajiba- Page 42)

It is said that Dhikr is a figure for the soul in which a person can preserve what he possesses of knowledge, and it is like memorization, except that memorization is said about achieving it while Dhikr is said with regard to recall it. It also said that it refers to recalling the thing by heart or saying which is why the Dhikr is said to be of two types: Heart Dhikr and Tongue Dhikr. (Al-Raghib- Page 184) 


\section{Sufism in Malaysia and its impact on the revival of the Islamic Dawah}

Of the abovementioned meaning of Dhikr linguistically and technically, we conclude the following:

1- The linguistic subject matter of Dhikr revolves around: First: Masculinity versus femininity and the like, Second: Antonym of forgetfulness.

2- There are other meanings for Dhikr some of which are: repute and praise, honor, prayers, Du`aa, reciting Qur'an, Tasbih, glorifying, and other meanings.

3- Dhikr may be practiced by tongue or heart, and both are essential.

\section{Second: Prominence and Levels of Dhikr}

Dhikr has a great prominence and significance that Imam Ibn alQayyim has explained in his book «Madaarij Saalikeen»saying:

The prominence of Dhikr: is the greatest prominence for the people from which they are obtained, trade, and always turn back to. Dhikr is authentication of the person those who are granted it, is connected through it and those who are deprived of it are abandoned. It is what keeps the hearts of people alive, where if it is to be gone the bodies are vacant as the lifeless. It is the structure of a house where if it is faulty, it will be left a wasteland and the weapon, they can face bandits with. It is the water they use to relieve the road sore, the medicine to their sorrows that if gone the hearts regress, and the cause and link that is between them and the Knower of the Unseen. It is what pushes back all evil, what clears away all hardships, and what mitigates all calamities. If a misfortune touches them; they seek it, and if the troubles rained down on them; they seek it, as it is the evergreen paradise that they rest in and the capital of their happiness that they trade with. The miserable heart departs it with joyful laughs, and it connects the reciter of Dhikr to Allah and part with it remembered.

All organs perform temporary acts of Obedience that it performs where Dhikr is the act of heart and tongue and it constant, as they are commanded to always remember (Dhikr) Allah who they worship and devote 
Amr Mohamed Sayed Imam\& Mohamed Ebrahim El-Sherbiny Sakr 142

themselves to in all positions: standing, sitting, and laying on the side. Jannah has a leveled land and Dhikr is the plants growing in it and the hearts are wastelands and Dhikr is its structure and foundation.

It is the clarity and polish of hearts, and the medicine if with sickness it were coated. The more the reciter of Dhikr develop in their Dhikr, the more Allah want to meet them and if the heart was used to Dhikr due to the tongue: they were to forget all but Dhikr and Allah would preserve all for them and would compensate them for all.

By Dhikr the deafness leaves ears, muteness relief the tongues, and the light replaces darkness in the eyes. Allah adorns the tongues of those who recite Dhikr as He adorned the eyes of lookers with lights, the forgetful tongue is as: a blind eye, deaf ear, and paralyzed hand and it is considered the greatest open door between Allah and worshipers as long as the worshiper does not close it with their forgetfulness. (Ibn al-Qayyim, 1419 A.H. Edition, 2/321/322)

The levels of Dhikr were also addressed by Ibn al-Qayyim - May Allah be merciful to him- and he concluded it in three levels by the author of Manazil al-Sairin -Imam al-Herawi-:

«First level: Evident Dhikr of: praise, Du`aa, or remembrance.

The Evident is: what is repeated by the tongue mirroring the heart, not only by the tongue as those are not relevant. Dhikr of praise is similar to: Subhan Allah wa Al-Hamdulillah wa La Ilaha Illa'llah wa Allah Akbar. (Glory be to Allah, Praise be to Allah, there is no Allah but Allah, and Allah is the Greatest)

Dhikr of Du'aa is similar to: “... "Our Lord! We have wronged ourselves. If You do not forgive us and have mercy on us, we will certainly be losers." (Al-A'raf: Verse 23)

Dhikr of remembrance is similar to: Allah is with me, Allah is seeing me, Allah is my witness, and similar things said to strengthen connections with Allah and it includes fostering the benefits of the heart, to be 


\section{Sufism in Malaysia and its impact on the revival of the}

Islamic Dawah

disciplined with Allah, be free of forgetfulness, and be preserved form Shaitan and from the self.

Second level: Dhikr Al-Khafi: It is the salvation of restrictions and staying in shohod and the imperative of night prayer dhikr.

Dhikr Al-Khafi here: is the salvation of restrictions and including the thoughts, this the benefit of the first dhikr, by the salvation of restrictions meant: getting rid of Inattention, forgetfulness and blocking between the heart and Allah who is glorious and exalted, by staying in shohod meant: worship Allah as if you see him, and if you do not achieve this state of devotion, then (take it for granted that) Allah sees you."

sticking to night prayer dhikr is heart supplication to Allah, to exaggerate in praise at times, attached at times, plaudit at times and respect at times again, and more of other types of confidential and by heart supplication.

Third level: Al-dhikr Al-haqiqi (the real dhikr): and it is that Allah's dhikr to you and getting rid of shohod of your dhikr, and it called dhikr haqiqi (real dhikr) because it is attributed to Allah Almighty, as for the ratio of dhikr of servant, it is not real, Allah's dhikr of his servant is Al-dhikr Al-haqiqi (the real dhikr), and it is Allah's dhikr shohod to his servant, and that he mentioned it to those who singled it out and his family close to him, and to his dhikr of him in fact: is the dhikr of Allah himself by making his servant and the servant's family invoke the name of Allah." (Ibn Qayyim, edit 1419 Hijri - 2/230 - 332.)

These levels of dhikr: loud dhikr, confidential and Al-dhikr Alhaqiqi (the real dhikr) supplication, the second level is the result of the first and the third is the result of the second.

\section{Third: Dhikr in congregation and loudly}

The scholars differed on the matter of dhikr in congregation and pronouncing it according to two opinions, some of them allowed it, and some of them prevented it. 


\section{Amr Mohamed Sayed Imam\& Mohamed Ebrahim El-Sherbiny Sakr 144}

\section{The arguments of those who say it is permissible to dhikr in congregation and loudly:}

Some scholars are of the view that it is permissible to dhikr in congregation and pronouncing it, among these are Imam Al-Nawawi, Al-Suyuti, Al-Leknawi and others ...

Imam Al-Nawawi in the book "Riyadh Al-Salihin" created a chapter with a title with this translation: Chapter on the merit of shaving the remembrance and wailing to be with it and forbidding it to leave her without an excuse.

He mentioned in it a number of Hadiths Sahih (authentic) of the Messenger of Allah (may Allah's prayers and peace be upon him) and beginning this Chapter with what Allah Almighty said And patiently stick with those who call upon their Lord morning and evening, seeking His pleasure (Al-Kahf: 28).

Among these hadiths: Abu Huraira and Abu Said reported the Messenger of Allah as saying, "People will not sit remembering Allah without the angels surrounding them, mercy covering them, peace descending on them, and Allah mentioning them among those who are with Him." Muslim transmitted it - the book of Dhikr and Supplication, Chapter: The merit of meeting over reciting the Qur'an and over remembrance, No: 2700.

And among those who stated that it is desirable to meet dhikr, Imam AlSuyuti in a chapter he named "As a result of thinking in the face of the dhikr" within his book "Al-Hawi for Fatwas" More than twenty hadiths have been mentioned in it indicating the desirability of making dhikr loudly as a statement or commitment and meeting with it. He concluded this chapter by responding to what was reported on the authority of Ibn Masoud (may Allah be pleased with him) that he saw a people cheering by raising their voice in the mosque, so he said: I only see your innovators until he drove them out of the mosque.

Al-Suyuti said: This narration on the authority of Ibn Massoud needs to be indicated by its supported, and whoever included it among the Imams, has preserving in their books and appreciated its provenness, so it 


\section{Sufism in Malaysia and its impact on the revival of the Islamic Dawah}

is opposed to the many proven hadiths mentioned above, which are presented to him when contradictory. Then I saw what necessitates a denial of that on the authority of Ibn Masoud, Imam Ahmad Ibn Hanbal said in the book "Zuhd" on the authority of Amer bin Shaqiq on the authority of Abu Wael, said: Those who claim that Abdullah bin Masoud used to forbid remembrance of dhikr, as Abdullah bin Masoud never sat in a sitting except Allah was mentioned in it and Ahmad narrated in "Zuhd" on the authority of Thabet Al-Banani, who said: The people of the remembrance of Allah are to sit for the remembrance of Allah and Allah, and that they have sins such as mountains, and that they will rise from the remembrance of Allah Almighty what they owe something of them. (Al-Suyuti, 1 / 466472.)

And among those who went to the legitimacy of dhikr in congregation and loudly, the investigator Imam Abd al-Hayy al- Laknawi in his book "Thought Swimming to speak loudest". In this chapter he has fulfilled the evidence of those who refuse to collective dhikr and the answer thereto, then he cited (48) evidence for the permissibility of dhikr publicly and in congregation, and between the citizen who asks for or dislikes it out loud, its conditions and etiquette, etc. The scholar Abd al-Fattah Abu Ghuddah took care of this chapter - may Allah have mercy on him Among the evidence mentioned by Imam Al-Laknawi ... what Al-Hakim narrated on the authority of Shaddad Bin Awas (may Allah be pleased with him), who said: We are with the Messenger of Allah (may Allah's prayers and peace be upon him) said: "Take your hands away and say There is no deity but Allah." So we raised our hands for an hour, then the Messenger of Allah (may Allah's prayers and peace be upon him) put his hand and said: "Praise be to Allah, Oh Allah, you sent me this word, and ordered me out , and Omrtne them paradise , you do not leave" (Compiled by AlHakim in Al-Mustadrak, The Book of Supplication 1/501, Al-Dhahabi said: Rashid weakened him by Daaraqutni and others, and Damim trusted him, and Al-Haythami said: 10/81 It was narrated by Ahmad and it was included by Rashid bin Dawood, and more than one documented it and had weakness and the rest of his men are trustworthy. 


\section{Amr Mohamed Sayed Imam\& Mohamed Ebrahim El-Sherbiny Sakr 146}

It was stated in the Modern Jurisprudence Encyclopedia:

The Committee considers that the participation of a group in adhkaar narrated, supplications contained or the reading of the Qur'an in one voice may be permitted provided that: Not to disturb the worshippers or others of their legitimate work, especially if this method helps the activity and teach the uneducated, provided that this method does not believe that it is obligatory or enacted in its own way, it is a means of teaching the uneducated, and to cooperate on righteousness and piety.

The committee also points out that some Maliki scholars have a fatwa in this regard looking at the (Arabic Standard Book) by Ahmed bin Yahya Al-Wonsharisi Al-Maliki. Al-Nawawi also based on the permissibility of raising the voice in dhikr on a hadith in the two Sahih, on the authority of Ibn Abbas that raising the voice in dhikr when people depart from the written was during the time of the Messenger of Allah (may Allah's prayers and peace be upon him), Ibn Abbas said: «I would have known if they were to go with that if I heard it ...» (Al-Bukhari included it in Literature book, chapter: Dhikr after the Prayer (841), and Muslim in the Book of Mosques and Places of Prayer, chapter: Dhikr after the Prayer (583), p. 141).

What I prefer from these two sayings is the saying that says that it is permissible to dhikr in congregation and loudly, but with its conditions, and these conditions were outlined by Zarrouk Al-Fassi in his rules by saying:

"The conditions in its conditions are necessary for its purpose, or it is not true for its existence, and if its image is established. There are three conditions for dhikr that must be met when combined:

First: The absence of time from a certain duty or delegate whose work requires a breach of it, such as staying awake and falling asleep for prayer, or being heavy with it, or neglecting it, or hurting his family, etc. 


\section{Sufism in Malaysia and its impact on the revival of the Islamic Dawah}

Second: Being free from something forbidden or something disliked that is associated with it, such as hearing women, attending them, or avoiding events, or intending to eat food that is not close to it, or suspiciousness of it even if I say, or forbidden bed like silk and the like, or mentioning the misfortunes of people ....

Third: Commitment to manners of dhikr whether it is legal or in its meaning, so that it is in what is correct and clear and mentioned in the face of tranquility, and if with standing up once and again, not with dancing and shouting and the like, then it is from the action of insane as Malik indicated - may Allah have mercy on him - when he was asked about them and said: (Are they insane?) and the purpose of his words is to praise in a way in which the prohibition is more appropriate, so understand, and Allah Almighty knows best." (Ibn Zarrouk, p. 84-85.)

It is clear from the foregoing the opinions of the scholars on the collective rule of dhikr, which in its entirety clarifies to us that establishing this virtue is not described as denied heresy.

The fact that the Malaysians were keen on a collective dhikr after prayer, and the dhikr councils that are held in homes on some days, such as Thursday, for example or in religious occasions such as the birth of the Messenger of Allah - may Allah's prayers and peace be upon him - or half of Shaban, as well as in the emigration of the Messenger of Allah - may Allah's prayers and peace be upon him - has an effect on the building of a Muslim in terms of increasing faith, there is no doubt that increasing faith prompts the Muslim to be a righteous man in the society in which he lives, and this is a practical call to Islam, and I have participated in many of these councils and found that the heart may be suspended and preoccupied with some worldly matters, then the heart will soon reassure, and the soul They stabilize, and the feelings of faith rise above all that preoccupies the heart after the tongue repeats close to fifty times, "There is no deity but Allah", dhikr while listening in congregation and chanting in congregation has the effect of leaving the state of negligence to awakening, and as the knowledgeable say is the beginning of the vigilant way. The waking of the heart 
through these councils is a tangible feeling, and it influences the revival of Islam in the Muslim heart in Malaysia, and it is a departure from the substance that has prevailed over lots.

\section{Third Topic: Reading Surat Yasin}

Among the traditions that keen by Muslims in Malaysia councils on Thursday, which are often held to read the Surah Ya-Sin in congregation, then followed by supplication, and these councils are also held in religious institutes, homes, and schools when they descend, which are good traditions that bring Muslims together on the Book of Allah, instill in the heart of the youth the sincerity of orientation when adversity, and in this topic we present this issue and the opinion of scholars on it.

In the merit of Surah Ya-Sin, the Messenger of Allah, may Allah's prayers and peace be upon him, said: "Surah Ya-Sin is the heart of the Qur'an, no man can recite it who wants Allah and the hereafter except for him, forgive him, and recite it upon your death." (Collected by Ahmed (5/26, No. 20315), and Al-Tabarani (20/220, No. 511). Al-Haythami said (6/311): In Sunan Abu Dawud, there is a party narrated by Ahmed, and in it there is an unnamed narrator, and the rest of his men are the men of AlSahih).

And the Messenger of Allah, may Allah's prayers and peace be upon him said: (And if the heart of the Qur'an is Surah Ya-Sin, whoever reads it is as if he has read the Qur'an ten times) (Compiled by Al-Darami (2/548, No. 3416), Al-Tirmidhi: 5/162, No. 2887), and he said: It is strange, and the hadith is weak.)

And his saying: "Whoever recites Surah Ya-Sin on a day and night with the desire of Allah, may Allah be glorified and exalted, may Allah forgive him" (Sahih Ibn Hibban, No. 2574 and it is authentic, and its chain of transmission is trustworthy and there is evidence for the hadith.) 


\section{Sufism in Malaysia and its impact on the revival of the Islamic Dawah}

From the total of what has been mentioned about it, we know that it has merit, just as some of the chapters of the Qur'an have more than the general merit of the Qur'an to encourage reading it. These hadiths can be considered in the virtues of deeds.

The jurists 'differed on the issue of reading the Qur'an in congregation, some of them disliked it, and the public went to the permissibility of it, and some saw it as desirable.

The doctrine of Hanbali and Shafi is desirable, this is the second view of the Hanafis: They quoted evidence for that with evidence indicating the general desirability of dhikr, as in his saying, may Allah's prayers and peace be upon him:

"Those persons who assemble in the house among the houses of Allah (mosques) and recite the Book of Allah and they learn and teach the Qur'an (among themselves) there would descend upon them tranquility and mercy would cover them and the angels would surround them and Allah mentions them in the presence of those near Him" (Sahih Muslim -The book of remembrance, supplication, repentance, and forgiveness - Chapter on the merit of reciting the Qur'an and on the dhikr - No. 2699)

Imam Ibn Rajab Al-Hanbali, may Allah have mercy on him, said after stating the difference on this issue:

"The majority of people inferred to the desirability of meeting to study the Qur'an in its entirety with hadiths indicating the desirability of meeting dhikr, the Qur'an is the best type of dhikr. (Ibn Rajab, 1422 AH - 2001 AD, Part 2, p. 303).

Imam Ibn Taymiyyah, may Allah have mercy on him, said: (Read good administration when most of the scholars and read the administration reading together with one voice and Malkiya has two sides in disliked it and Malik disliked it) (Ibn Taymiyyah, Part 5/344).

Imam Al-Nawawi saw that what was reported by Imam Malik, may Allah have mercy on him, regarding the dislike of reciting the 


\section{Amr Mohamed Sayed Imam\& Mohamed Ebrahim El-Sherbiny Sakr 150}

Qur'an in congregation, contrary to what is required of most scholars. He, may Allah have mercy on him, said: On the authority of Wahb, he said: I said to Malik, have you seen the people get together and they all read one surah until they complete it? So he denied and malice it, and said this is not what people do. Rather he used to read a man against the other as an objection. This denial of them is contrary to what the predecessor and backer had to do and when the evidence requires it is forsaken, and reliance on the foregoing is desirable. (Al-Nawawi, 1414 AH - 1994 AD, p. 102)

Moreover, the denial of Malik, may Allah Almighty have mercy on him, on this issue does not mean that it is forbidden or from heresy. The General Maliki jurists interpret the words of Malik, may Allah have mercy on him, on this issue. So Imam Al-Wonsharisi, may Allah have mercy on him, said, summarizing this issue in Malik's doctrine, the Messenger of Allah, may Allah's prayers and peace be upon him said: "those persons who assemble in the house among the houses of Allah (mosques) and recite the Book of Allah and they learn and teach the Qur'an (among themselves) there would descend upon them tranquility and mercy would cover them and the angels would surround them and Allah mentions them in the presence of those near Him", Imam Al-Mazri said: Its apparent meaning meaning the hadith - is permissible to meet to read the Qur'an in the mosques, even if Malik disliked that in the Moudawana, and perhaps he only said that because he did not see the predecessors doing it while they were keen on doing good, some of the sheikhs said: Perhaps it is a good innovation, such as voluntary night prayer "qiyam" in Ramadan and other things and the command over him in our country was between scholars, and the matter concerning it is light. I said: The matter was applied to him in all of the Maghreb, and indeed in the East, in what we reached and not denying, and it is nothing but cooperation in righteousness and good deeds, and a means for the activity of the lazy, and they have stipulated that the rule of means is the rule of the one who is supplicated. (Al-Wancharisi, part 1, p. 155) 


\section{Sufism in Malaysia and its impact on the revival of the Islamic Dawah}

It is clear from the foregoing that the scholars said in the reading of Surah Ya-Sin in congregation, and in explaining their opinions, what drives the suspicions of those who describe this tradition as heresy.

Reading Surah Ya-Sin in the manner that Muslims do in Malaysia is a good tradition, and it has its effect on improving the reading of the Qur'an and societal connectedness, it also has an impact on reviving the call of Islam, as many of these councils take place in homes, which is often bordered by non-Muslims, so that would be a clear sign and a visible ritual of Islam, it is also an invitation to non-Muslims to learn about this religion through some rituals, in which it shows friendliness, love and interconnectedness between the Muslim community.

\section{CONCLUSION}

All praise is to Allah and peace and blessings be on the Messenger of Allah, and upon his family and companions and those who follow him.

There are some results that came out of this research after exposure to a study of Sufism tendency in Malaysian society and its impact on Da'wah, and these are some of the results that came out of the research:

1. Being keen on the dhikr contained in many hadiths is one of the customs that Muslims practice in Malaysia, and it is a good habit.

2. Muslims in Malaysia adhere to the texts mentioned by the Messenger of Allah (Allah's blessing and peace be upon him), and also take some letters from the Scholars of Sufism.

3. We cannot describe these practices as heresy, as there is no prohibition against them, but the Islamic Sharia came to confirm it.

4. Muslims in Malaysia observe the demonstration of religious rituals through Tahlil assemblies, and that is an invitation to Islam.

5. Muslims in Malaysia recite Yaseen while making sure to pray permanently on Thursday (Friday night), and this is what instills faith in hearts.

6. Documenting roots in the Shari'for the dhikr that Muslims in Malaysia are keen on in this research is a response to those who claim heresy. 
Praise be to Allah, Lord of all creation

\section{References}

The Holy Quran

Ibn-Manẓūr, Muḥammad Ibn-Mukarram, Lisan Al-Arab, Beirut, Dar

Sader, Edition: Third, 1414 Ah

Abu Dawood, Suleiman Bin Al-Ash'ath. (1419 Ah, 1998 Ad). Sunan Abi Dawood. Investigation By: Muhammad Awama. 2nd I:

Beirut: Al-Qibla House.

Al-Bukhari, Muhammad Bin Ismail. (1407 Ah - 1987 Ad). Al-Jami 'AlSahih Al-Muqtasar, I 3. Beirut: Dar Ibn Kathir.

Al-Razi, Muhammad Bin Abi Bakr, 1420 Ah -1999 Ce Mukhtar As-Sahah, Edited By: Youssef Al-Sheikh, 5th Edition, Beirut: The Modern Library.

Al-Ragheb Al-Isfahani, Al-Hussein Bin Muhammad, Vocabulary In Gharib Al-Qur'an, Cairo, Al-Tawfiqia Library.

Al-Zubaidi, Sayyid Muhammad Mortada, 1306 Ah, Taj Alarus From Jawahir Al-Qamous Jewels, 1st Floor, Cairo, Almaktabah Alasriah.

Al-Zuhaili, Wahba, Islamic Jurisprudence and Its Evidence. I 4. Damascus: Dar Al-Fikr.

Al-Bayanouni, Muhammad Abu Al-Fateh, 1991 Ad, Introduction To The Science Of Da'Wah, Beirut: The Resala Foundation 


\section{Sufism in Malaysia and its impact on the revival of the}

Islamic Dawah

Al-Ghazali, Muhammad. With Allah, Egypt. Modern Book House.

Muslim, Abu Al-Hasan Al-Qushayri Al-Nisaburi. (I 1374 Ah / 1955 Ce). The Musnad Alsahih Almukhtasar , Edited By: Muhammad Fuad Abd Al-Baqi, Cairo: House Of Ehiaa Arab Books.

Mustafa, Ibrahim.Almugam- Al-Waseet, Edited By: The Arabic Language Academy. Cairo: Dar Al Da`Wah.

Al-Khalidi, Abdul Salam Al-Amrani, 2018.Alakmar Almushrikah Liahli Alshariah And Altarikah And Haqiqah , Beirut: Dar Al-Kutub AlIlmiyya.

Al-Nawawi, Yahya Ibn Sharaf, Al-Minhaj Bi Sharh Sahih Muslim Ibn AlHajjaj, Beirut, Dar 'Iihya' Al-Turath Al-Arabii, Second Edition, 1392 A.H. 